\title{
PENEGAKAN HUKUM TERHADAP PERDAGANGAN MANUSIA BERKEDOK PENGIRIMAN PEKERJA MIGRAN INDONESIA
}

\author{
Oleh: \\ Mahendra Kusuma, SH, MH \\ (Dosen Tetap FH Universitas Tamansiswa Palembang)
}

\begin{abstract}
ABSTRAK
Salah satu bidang dalam sektor ekonomi Indonesia bekerja sama dengan negaranegara lain adalah sektor ketenagakerjaan. Indonesia membutuhkan dan menerima tenaga kerja asing. Pada saat yang bersamaan, Indonesia mengirim tenaga kerja ke luar negeri. Namun, penempatan tenaga kerja di luar negeri selama ini justru mengiris hati sebagaian besar rakyat Indonesia. Hampir setiap hari, rakyat Indonesia mendengar, menonton, dan membaca berita tentang permasalahan yang dialami calon tenaga kerja Indonesia dan pekerja migran Indonesia baik pra-pemberangkatan, di tempat kerja di negara penempatan, maupun di bandara Soekarno-Hatta ketika mereka kembali ke tanah air.Dalam praktek seringkali perekrutan pekerka migran Indonesia dilakukan oleh mafia yang menarik keuntungan dari calon pekerja migran. Para mafia biasanya menawarkan sebagai TKW/TKI baik dalam maupun luar negeri dengan iming-iming gaji yang tinggi..
\end{abstract}

Kata Kunci: Penegakan Hukun, Perdagangan Manusia, Pekerja Migran

\section{A. Latar Belakang}

Negara itu ibarat manusia tidak mungkin bisa hidup tanpa manusia lainnya. Saling membutuhkan. Ada kekurangan dan kelebihan, saling mengisi. Demikian juga negara, ada kelebihan dan kekurangan. Karena itu, semua negara di dunia pasti bekerja sama dengan negara lainnya, baik dalam bidang ekonomi maupun sosial dan politik.

Adanya kesenjangan pendapatan antarnegara menyebabkan semakin menipisnya peluang untuk dapat mencapai tingkat kehidupan yang lebih baik secara politik, ekonomi, sosial, budaya dan keamanan, terutama perbedaan tingkat pendidikan dan penguasaan ilmu pengetahuan serta perkembangan teknologi.

Ketidakseimbangan ini akan memberikan peluang yang lebih besar kepada negaranegara maju dan beberapa negara berkembang yang memiliki tingkat penguasaan teknologi, edukasi, dan kapital yang cukup memadai untuk mengatasi masalah-masalah yang dihadapi secara lebih baik.

Keadaan ini secara global akan mendorong terjadinya peningkatan arus pergerakan manusia tidak saja dalam lingkup domestik dan regional tetapi juga internasional. Manusia 
bergerak hanya untuk mendapatkan pekerjaan demi kehidupan yang lebih baik. ${ }^{28}$ Karena itulah, terdapat kerja sama antarnegara. Kerja sama ini bukan didorong kepentingan pribadi manusia semata tetapi karena adanya pasar bebas.

Salah satu bidang dalam sektor ekonomi Indonesia bekerja sama dengan negaranegara lain adalah sektor ketenagakerjaan. Indonesia membutuhkan dan menerima tenaga kerja asing. Pada saat yang bersamaan, Indonesia mengirim pekerja migran Indonesia ke luar negeri.

Bekerja di mana saja, termasuk di luar negeri adalah hak setiap warga negara, dan merupakan salah satu hak asasi manusia. Hak asasi warga Indonesia untuk mendapatkan pekerjaan diatur secara jelas dalam Pasal 27 ayat (2) UUD 1945 yang berbunyi, "Tiap-tiap warga negara berhak atas pekerjaan dan penghidupan yang layak bagi kemanusiaan".

Penempatan tenaga kerja di luar negeri ini diatur dalam Undang-Undang Nomor 13 Tahun 2003 tentang Ketenagakerjaan. Dalam Pasal 33 undang-undang tersebut dinyatakan bahwa "Penempatan Tenaga Kerja terdiri dari: (a) penempatan tenaga kerja di dalam negeri, (b) penempatan tenaga kerja di luar negeri". Selanjutnya Pasal 34 menyatakan bahwa "Ketentuan mengenai penempatan tenaga kerja di luar negeri sebagaimana dimaksud dalam Pasal 33 huruf b diatur dengan undang-undang".

Yang dimaksud dengan diatur dengan undang-undang dalam Pasal 34 UU No. 13 Tahun 2003 adalah Undang-Undang Nomor 39 Tahun 2004 tentang Penempatan dan Perlindungan Tenaga Kerja Indonesia di Luar Negeri. Namun undang-undang ini dianggap kurang memberikan perlindungan hukum terhadap TKI di luar negeri, sehingga undangundang ini diganti dengan Undang-Undang Nomor 18 Tahun 2017 tentang Perlindungan Pekerja Migran Indonesia.

Penempatan tenaga kerja di luar negeri selama ini justru mengiris hati sebagaian besar rakyat Indonesia. Hampir setiap hari, rakyat Indonesia mendengar, menonton, dan membaca berita tentang permasalahan yang dialami calon tenaga kerja Indonesia dan pekerja migran Indonesia baik pra-pemberangkatan, di tempat kerja di negara penempatan, maupun di bandara Soekarno-Hatta ketika mereka kembali ke tanah air.

Dalam praktek seringkali perekrutan pekerja migran Indonesia dilakukan oleh mafia yang menarik keuntungan dari calon pekerja migran. Para mafia biasanya menawarkan sebagai Pekerja Migran Indonesia (PMI) baik dalam maupun luar negeri dengan iming-iming gaji yang tinggi. Yang melakukan ini adalah Perusahaan Penempatan Pekerja Migran hlm. 5

${ }^{28}$ M. Iman Santoso, Perspektif Imigrasi dalam Migrasi Manusia, Pustaka Reka Cipta, Bandung, 2014, 
Indonesia (P3MI) melalui Petugas Lapangan (PL) yang mendatangi kampung-kampung untuk mengiming-imingi seseorang atau warga untuk bekerja ke luar negeri dengan mendapatkan upah atau penghasilan dengan jumlah besar dan jika petugas lapangan ini berhasil mendapatkan Calon Pekerja Migran Indonesia (CPMI), setiap Pekerja Migran Indonesia (PMI) mendapat imbalan yang besarnya berbeda-beda.

Mereka yang direkrut biasanya ditempatkan pada sebuah pemondokan atau tempat penampungan. Umunya, tempat itu sangat tertutup dan tidak memungkinkan mereka berkomunikasi secara fisik dengan pihak lain, kecuali atas izin perekrut. Di negara tujuan kadangkala mereka bekerja tidak sesuai dengan apa yang dijanjikan sewaktu di kampung. Bahkan ada yang dijadikan sebagai wanita penghibur dengan pengawasan ekstra ketat, tidak dapat kembali ke tanah air dalam waktu tertentu.

Bentuk-bentuk perdagangan orang yang terjadi disuatu negara dengan negara lain memiliki karakteristik yang berbeda, tetapi secara umum bentuk-bentuknya meliputi eksploitasi seksual, kerja paksa, perbudakan dalam rumah tangga, adopsi anak antarnegara secara ilegal, penjeratan utang, pengantin pesanan, dan perdagangan organ tubuh manusia. ${ }^{29}$

Data Badan Nasional Penempatan dan Perlindungan Tenaga Kerja Indonesia (BNP2TKI) selama tahun 2010 mencatat, sebanyak 1.087 kasus kekerasan terhadap TKI terjadi di seluruh negara penempatan. Sedangkan dalam data Migrant Care, sepanjang tahun 2010, situasi buruh migran Indonesia, terutama PRT (Pekerja Rumah Tangga) migran, berada pada tingkat yang sangat memprihatinkan. Tercatat, 89.544 buruh migran menghadapi berbagai bentuk persoalan di 42 negara tujuan. ${ }^{30}$

Pemerintah bertugas mengatur, membina, melaksanakan, dan mengawasi penyelenggaraan penempatan dan perlindungan TKI di luar negeri. Dalam melaksanakan tugas tersebut, Pemerintah dapat melimpahkan sebagai wewenangnya dan/atau tugas perbantuan kepada pemerintah daerah sesuai dengan peraturan perundang-undangan. ${ }^{31}$

\section{B. Permasalahan}

Dari apa yang telah diuraikan dalam latar belakang di atas, maka permasalahan yang diambil dalam penulisan ini adalah sebagai berikut: Bagaimanakah penegakan hukum terhadap perdagangan manusia berkedok pengiriman pekerja migran Indonesia?

${ }^{29}$ Mahrus Ali dan Bayu Aji Pramono, Perdagangan Orang: Dimensi, Instrumen Internasional, dan Pengaturannya di Indonesia, Citra Aditya Bakti, Bandung, 2011, hlm. 24

${ }^{30}$ Suara Pembaruan, tanggal 10 Desember 2012

${ }^{31}$ R. Joni Bambang S, Hukum Ketenagakerjaan, Pustaka Setia, Bandung, 2013, hlm. 257 


\section{Pembahasan}

Penegakan hukum pada hakikatnya merupakan suatu usaha untuk mewujudkan ide-ide keadilan, kepastian hukum, dan kemanfaatan sosial. Dalam kontek yang lebih berfokus pada kinerja penegak hukum. Paul SinlaEloE berpendapat bahwa penegakan hukum dipahami sebagai suatu rangkaian kegiatan dalam rangka pelaksanaan ketentuan-ketentuan hukum baik yang bersifat penindakan maupun pencegahan yang mencakup seluruh kegiatan baik teknis maupun administratif yang dilaksanakan oleh aparat penegak hukum sehingga nilai-nilai dasar dari hukum, yakni keadilan, kemanfaatan dan kepastian dapat terwujud. ${ }^{32}$

Kejadian-kejadian dalam kasus perdagangan manusia orang umumnya diawali dengan modus bantuan administrasi dan persyaratan kerja, walaupun pada ahirnya merupakan penjeratan hutang. Dalam kasus pekerja migran, modusnya antara lain: gaji ditahan, hanya diberikan sebagian atau bahkan tidak diberikan sama sekali. Hutang dipotong langsung oleh majikan dari upah tanpa persetujuan/kontrol dari korban. Setelah pulang ke daerah asal sering korban diminta uang sebagai balas jasa atas bantuan dalam pengiriman ke tempat bekerja. Buruh tidak boleh pindah bekerja/tanpa seijin/sepengetahuan dari calo/sponsor/penyalur.

Tidak semua tindak pidana perdagangan orang selalu melanggar aturan hukum (hukum pidana) saja, tetapi dapat juga melanggar lebih dari satu aturan/undang-undang. Karena itu, dalam menerapkan sanksi hukum bagi pelaku sudah selayaknya mendapat sanksi pidana penjara (penal) dan sanksi administrasi lainnua (non penal), agar menimbulkan efek jera bagi pelaku.trafficker. ${ }^{33}$

Ada perbedaan mendasar penyelesaian kasus tindak pidana perdagangan orang (TPPO) dengan kasus-kasus pidana lainnya adalah perlakuan terhadap korban. Hal ini sesuai dengan amanat Pasal 28 UU PTPPO, bahwa: Proses beracara mulai dari penyidikan, penuntutan dan pemeriksaan di sidang pengadilan, terkait penegakan hukum terhadap suatu TPPO, berpedoman pada hukum acara pidana kecuali ditentukan lain dalam UU PTPPO.

Dalam Pasal 29 UU PTPPO disebutkan bahwa alat bukti selain sebagaimana ditentukan dalam KUHAP, dapat pula berupa: Pertama, informasi yang diucapkan, dikirimkan, diterima, atau disimpan secara elektronik dengan alat optik atau yang serupa dengan itu; dan Kedua, data, rekaman, atau informasi yang dapat dilihat, dibaca, dan/atau didengar yang dapat dikeluarkan dengan atau tanpa bantuan suatu sarana, baik yang tertuang di atas kertas, benda fisik apa pun selain kertas, atau yang terekam secara elektronik, termasuk

\footnotetext{
${ }^{32}$ Paul SinlaEloE, Tindak Pidana Perdagangan Orang, Setara Press, Malang, 2017, hlm. 51

33 Henny Nuraeny, Tindak Pidana Perdagangan Orang: Kebijakan Hukum Pidana dan Pencegahannya, Sinar Grafika, Jakarta, 2011, hlm. 379-380
} 
tidak terbatas pada (1) Tulisan, suara, atau gambar; (2) Peta, rancangan, foto, atau sejenisnya atau (3) huruf, tanda, angka, simbol, atau perforasi yang memiliki makna atau dapat dipahami oleh orang yang mampu membaca atau memahaminya.

Sebagai salah satu alat bukti yang sah, keterangan seorang saksi korban saja sudah cukup untuk membuktikan bahwa terdakwa bersalah, apabila disertai dengan satu alat bukti yang sah lainnya (Pasal 30 UU PTPPO). Berdasarkan bukti permulaan yang cukup Pasal 31 ayat (1) UU PTPPO membolehkan penyidik untuk melakukan penyadapan terhadap telepon atau alat komunikasi lainnya yang diduga digunakan untuk mempersiapkan, merencanakan, dan melakukan TPPO. Tindakan penyadapan dimaksud, hanya dilakukan atas izin tertulis ketua pengadilan untuk jangka waktu paling lama 1 tahun

Pasal 32 UU PTPPO memberikan kewenangan pada penyidik, penuntut umum, atau hakim untuk memerintahkan kepada penyedia jasa keuangan seperti penyedia jasa keuangan antara lain, bank perusahaan efek, reksa dana dan perdagangan valuta asing, untuk melakukan pemblokiran terhadap harta kekayaan setiap orang yang disangka atau didakwa melakukan TPPO. Dalam proses penyidikan, penuntutan, dan pemeriksaan di sidang pengadilan, pelapor berhak dirahasiakan nama dan alamatnya atau hal-hal lain yang memberikan kemungkinan dapat diketahuinya identitas pelapor.

Pelapor juga berhak meminta dirahasiakan nama dan alamatnya atau hal-hal lain. Karenanya, kewajiban merahasiakan identitas tersebut harus diberitahukan kepada saksi dan orang lain yang bersangkutan dengan TPPO sebelum pemeriksaan oleh pejabat yang berwenang untuk melakukan pemeriksaan.

Bagi setiap orang yang memberitahukan identitas saksi atau korban padahal kepadanya telah diberitahukan bahwa identitas saksi dan korban tersebut harus dirahasiakan, menurut Pasal 24 UU PTPPO, dipidana dengan pidana penjara paling singkat 3 tahun dan paling lama 7 tahun dan pidana denda paling sedikit Rp 120.000.000,- dan paling banyak Rp.280.000.000,-

Dalam hal saksi dan/atau korban tidak dapat dihadirkan dalam pemeriksaan di sidang pengadilan terkait kasus TPPO, keterangan saksi dapat diberikan secara jarak jauh melalui alat komunikasi audio visual (Pasal 34 UU PTPPO). Selama proses penyidikan, penuntutan, dan pemeriksaan di sidang pengadilan saksi dan/atau korban berhak: Pertama, didampingi oleh advokat dan/atau pendamping lainnya yang dibutuhkan (Pasal 35 UU PTPPO). Kedua, mendapatkan informasi tentang perkembangan kasus yang melibatkan dirinya. Informasi tentang perkembangan kasus dapat berupa pemberian salinan berita acara setiap tahap pemeriksaan (Pasal 36 ayat (1) dan ayat (2) UU TPPPO. Ketiga, meminta kepada hakim ketua 
sidang untuk memberikan keterangan di depan sidang pengadilan tanpa kehadiran terdakwa (Pasal 37 ayat (3) UU PTPPO).

Menurut Pasal 37 ayat (2) UU PTPPO, jika saksi dan/atau korban akan memberikan keterangan tanpa kehadiran terdakwa, hakim ketua sidang memerintahkan terdakwa untuk keluar ruang sidang. Selanjutnya pemeriksaan terdakwa dapat dilanjutkan setelah kepada terdakwa diberitahukan semua keterangan yang diberikan saksi dan/atau korban pada waktu terdakwa berada di luar ruang sidang pengadilan.

Dalam proses penyidikan, penuntutan, dan pemeriksaan di sidang pengadilan terhadap saksi dan/atau korban anak dalam kasus TPPO harus dilakukan dengan memerhatikan kepentingan yang terbaik bagi anak dengan tidak memakai toga atau pakaian dinas (Pasal 38 UU PTPPO). Sidang kasus TPPO untuk memeriksa saksi dan/atau korban anak dilakukan dalam sidang tertutup dan wajib didampingi orang tua, wali, orang tua asuh, advokat, atau pendamping lainnya (Pasal 39 ayat (1) dan ayat (2) UU PTPPO).

Pemeriksaan terhadap saksi dan/atau korban anak, juga harus dilaksanakan tanpa kehadiran terdakwa (Pasal 39 ayat (3) UU PTPPO). Pemeriksaan terhadap saksi dan/atau korban anak, atas persetujuan hakim, dapat dilakukan di luar sidang pengadilan dengan perekaman (alat rekam audio dan/atau audio visual) dan harus dihadapan pejabat yang berwenang, dalam hal ini penyidik atau penuntut umum (Pasal 40 ayat (1) UU PTPPO).

Pada proses persidangan, jika terdakwa telah dipanggil secara sah dan patut, tidak hadir di sidang pengadilan tanpa alasan yang sah, maka menurut Pasal 41 ayat (1) UU PTPPO, perkara dapat diperiksa dan diputus tanpa kehadiran terdakwa (sidang in absentia). Jika terdakwa hadir pada sidang berikutnya sebelum putusan dijatuhkan, maka terdakwa wajib diperiksa dan segala keterangan saksi dan surat yang dibacakan dalam sidang sebelumnya dianggap sebagai alat bukti yang diberikan dengan kehadiran terdakwa (Pasal 41 ayat (2) UU PTPPO).

Pelaku perdagangan manusia berkedok pengiriman pekerja migran dapat dijerat Pasal 4 dan Pasal 10 UU Nomor 21 Tahun 2007 tentang Pemberantasan Tindak Pidana Perdagangan Orang (TPPO), juga dapat dijerat dengan Pasal 81 dan Pasal 86 UU Nomor 18 Tahun 2017 tentang Perlindungan Pekerja Migran Indonesia.

Pasal 4 UU Nomor 21 Tahun 2007 (UU PTPPO) menyatakan bahwa: "Setiap orang yang membawa warga negara Indonesia ke luar wilayah negara Republik Indonesia dengan maksud untuk dieksploitasi di luar wilayah negara Republik Indonesia dipidana dengan pidana penjara paling singkat 3 (tiga) tahun dan paling lama 15 (lima belas) tahun dan pidana 
denda paling sedikit Rp 120.000.000,00- (seratus dua puluh juta rupiah) dan paling banyak Rp 600.000.000,00- (enam ratus juta rupiah). Sedangkan Pasal 10 menyatakan bahwa: 'Setiap orang yang membantu atau melakukan percobaan untuk melakukan tindak pidana perdagangan orang, dipidana dengan pidana yang sama sebagaimana dimaksud dalam Pasal 2, Pasal 3, Pasal 4, Pasal 5, dan Pasal 6".

Pasal 81 UU Nomor 18 Tahun 2017 menyatakan: "Orang perseorangan yang melaksanakan penempatan pekerja migran Indonesia sebagaimana dimaksud dalam Pasal 69 dipidana dengan pidana penjara paling lama 10 (sepuluh) tahun dan denda paling banyak Rp 15.000.000.000,00 (lima belas miliar rupiah)". Sedangkan Pasal 86 menyatakan: "Dipidana dengan pidana penjara paling lama 5 (lima) tahun dan denda paling banyak Rp 15.000.000.000,00,- (lima belas miliar rupiah), setiap orang yang:

a. Membebankan komponen biaya penempatan yang telah ditanggung calon Pemberi Kerja kepada Calon Pekerja Migran Indonesia sebagaimana dimaksud dalam Pasal 72 huruf a;

b. Menempatkan Calon Pekerja Migran Indonesia ke negara tertentu yang dinyatakan tertutup sebagaimana dimaksud dalam Pasal 72 huruf b;

c. Menempatkan Pekerja Migran Indonesia tanpa SIP2MI sebagaimana dimaksud pasal 72 huruf c;

d. Menempatkan Pekerja Migran Indonesia pada negara tujuan penempatan sebagaimana dimaksud dalam Pasal 72 huruf d."

Selain itu, pelaku pengiriman tenaga kerja migran Indonesia berkedok perdagangan orang juga dapat dijerat dengan Undang-Undang Nomor 23 Tahun 2002 tentang Perlindungan Anak, Undang-Undang Nomor 39 Tahun 1999 tentang Hak Asasi Manusia, dan UndangUndang Nomor 7 Tahun 1984 tentang Pengesahan Konvensi Mengenai Penghapusan Segala Bentuk Diskriminasi terhadap Wanita. ${ }^{34}$ Bahkan dapat juga dijerat dengan pasal Tindak Pidana Pencucian Uang (TPPU). Dengan jerat TPPU itu, harta kekayaan pelaku bisa disita karena bersumber dari hasil kejahatan. ${ }^{35}$

Beberapa kasus TPPO yang terjadi tidak selalu sampai ke pengadilan. Ada beberapa kasus yang dihentikan di tingkat penyidikan atau penuntutan, karena berbagai alasan (kurangnya alat bukti, pelaku yang tidak ditemukan alamatnya, dan lain-lain), tetapi ada juga yang sampai berlanjut pada tingkat Banding atau Kasasi ke Mahkamah Agung.

\footnotetext{
${ }^{34}$ S. Edi Hardum, S. Edi Hardum, Perdagangan Manusia Berkedok Pengiriman TKI, Ar-Ruzz Media, Yogyakarta, 2016, hlm. 137

${ }^{35}$ Majalah Hukum dan Politik Keadilan Indonesia Edisi 45 Tahun II/22 April-5 Mei 2019, hlm. 37
} 


\section{Penutup}

Penegakan hukum terhadap perdagangan manusia berkedok pengiriman pekerja migran Indonesia dilakukan mulai dari tahap penyidikan oleh kepolisian, penuntutan oleh pihak kejaksaan dan pemeriksaan pada sidang pengadilan. Proses beracara mulai dari penyidikan, penuntutan dan pemeriksaan di sidang pengadilan, terkait penegakan hukum terhadap suatu TPPO, berpedoman pada hukum acara pidana kecuali ditentukan lain dalam UU PTPPO. Ada pelaku TPPO yang berhasil dijerat dengan hukum, namun ada juga yang tidak bisa diproses hukum.

Kegiatan-kegiatan penyuluhan hukum (sosialisasi) kepada masyarakat perlu ditingkatkan sehingga kasus perdagangan manusia berkedok pengiriman pekerja migran tidak terjadi lagi, dalam bentuk sosialisasi undang-undang pemberantasan tindak pidana perdagangan orang dan undang-undang perlindungan pekerja migran Indonesia.

\section{DAFTAR PUSTAKA}

\section{A. Buku-Buku}

Henny Nuraeny, Tindak Pidana Perdagangan Orang: Kebijakan Hukum Pidana dan Pencegahannya, Sinar Grafika, Jakarta, 2011

M. Iman Santoso, Perspektif Imigrasi dalam Migrasi Manusia, Pustaka Reka Cipta, Bandung, 2014 ,

Mahrus Ali dan Bayu Aji Pramono, Perdagangan Orang: Dimensi, Instrumen Internasional, dan Pengaturannya di Indonesia, Citra Aditya Bakti, Bandung, 2011

Paul SinlaEloe, Tindak Pidana Perdagangan Orang, Setara Press, Malang, 2017

R. Joni Bambang S, Hukum Ketenagakerjaan, Pustaka Setia, Bandung, 2013

S. Edi Hardum, Perdagangan Manusia Berkedok Pengiriman TKI, Ar-Ruzz Media, Yogyakarta, 2016

\section{B. Peraturan Perundang-undangan}

Undang-Undang Nomor 13 Tahun 2003 tentang Ketenagakerjaan.

Undang-Undang Nomor 21 Tahun 2007 tentang Pemberantasan Tindak Pidana Perdagangan Orang.

Undang-Undang Nomor 18 Tahun 2017 tentang Perlindungan Pekerja Migram Indonesia. 